\title{
TREE STRATIFICATION BASED ON ERUPTION DAMAGE LEVEL IN MOUNT MERAPI NATIONAL PARK YOGYAKARTA INDONESIA
}

\author{
INGGita UTAMI ${ }^{\left.1,2^{*}\right)}$, RADHITIYA ANJAR PRAMANA PUTRA ${ }^{2)}$, MUHAMMAD SAPUTRA Wibowo $^{3)}$, ARVITENO \\ EKO $^{2)}$, FEBRIANT ISABELLA YUSUF $^{2)}$, FAHIMATUL HUSNA ${ }^{2)}$ AND DENNI SUSANTO ${ }^{4)}$
1) Laboratory Ecology and Systematics, Universitas Ahmad Dahlan, Kampus 4 Jl. Ringroad Selatan, Bantul, Yogyakarta, 55191, Indonesia
2) Department of Biology, Faculty of Applied Sains and Technology, Universitas Ahmad Dahlan
Jl. Ringroad Selatan, Bantul, Yogyakarta, 55191, Indonesia
3) Magister Biology, Faculty of Biology, Gadjah Mada University, Yogyakarta, 55281, Indonesia
4) Department of Bioresources Technology and Veterinary, Vocational College, Universitas Gadjah Mada, Yogyakarta, 55281, Indonesia

*Email: inggitautami@bio.uad.ac.id

Accepted February 23, 2021/Approved April 14, 2021

\begin{abstract}
Mount Merapi's eruption has caused damage to the forests in the Mount Merapi National Park (MMNP). Nine years after the eruption, the vertical structure of vegetation can illustrate the progress of succession. This study aimed to analyze the tree composition and stratification in different forest damage levels after the 2010 Merapi eruption. The study was conducted in March 2019 at three stations, namely station A (heavy damage area), station B (moderate damage area), and station $C$ (minor damage area). Vegetation parameters in each station were taken in a $10 x 100$ plot and were processed using a tree profile diagram. Abiotic parameters were measured in each plot and analyzed using the correlation test. The results showed that the three stations were still dominated by the tree in Stratum $C$, but the tree density and tree height varied in proportion to the damage level. Station A in the heavy damage area has the lowest tree density (23 trees/0.1 ha) with a maximum tree height of 12 meters, in contrast to Station $C$ in the minor damage area with tree density reaching 195 trees/0.1 ha and maximum tree height reaching 30 meters. Nine years after the Mount Merapi big eruption, the MMNP forests in Yogyakarta Province are still classified as young secondary forests.
\end{abstract}

Key words: diagram, profile, succession, structure, vertical

\section{INTRODUCTION}

Succession is a form of adaptation or natural recovery process on disturbed land, marked by changes in the vegetation community to achieve complex and stable conditions (Chokkalingam \& Jong 2001; Molles, 2008; Chang et al. 2019). The volcanic eruption is one of the disturbances that can change forest vegetation cover dan change the existing substrate (Rahayu et al. 2014). Many local people live around the volcano forest area using agriculture resources (Fitria \& Banowati 2018), livestock, and tourism (Muhamad 2017). Because the role of forest area in the volcano is significant for the ecosystem and people, the succession process after disturbance is also necessary to be studied to design strategies for forest rehabilitation as a basic for sustainable forest management (Sarmiento et al. 2003; Cakir et al. 2007; Prach \& Walker 2018). Vegetation structure can be used as an indicator in managing the post-disturbed ecosystem (Rutten et al. 2015).

Mount Merapi National Park (MMNP), located in Yogyakarta and Central Java Province, functions as a buffer for Mount Merapi (Afrianto et al. 2016). Mount Merapi is the most active volcano in Indonesia (Utami et al. 2018), even in the world, which has a constant eruption interval, and one of the largest occurred in 2010 (Surono et al. 2012; Troll et al. 2013). The disruption caused damage estimated at 38.3 trillion rupiahs, including ecological damage, the cost of decreasing carbon sequestration productivity, and restoration costs (Marhaento \& Kurnia 2015). Around 1.3 million people live up to $20 \mathrm{~km}$ from the Mount Merapi summit (Mei et al. 2013). As severe as disturbance occurs, the habitat, food sources, and sources of clean water for flora, fauna, and humans that live around Mount Merapi will be less frequent. Pioneer plant growth as a vegetation succession part of post-eruption has begun to be reported, especially in heavy damage area. Sutomo \& Fardila (2013) reported in 2011, five herbs, five shrubs, and five saplings were found in Kalikuning, while Sunardi et al. (2017) reported in 2014, 27 herbs, four saplings, and three poles were found in Cangkringan.

One of the factors that influence succession in nature is location conditions with varying disturbance levels (Meiners et al. 2014; Utami et al. 2021). The disturbance in location can trigger differences in succession in primary or secondary succession (Prach \& Walker 2018). According to McNaughton \& Wolf (1990), terrestrial succession in the former eruption area will start from volcanic ash deposits forming to the formation of forests in decades and even centuries. The soil in a forest contains reserves of pioneer plants in the form of dormant seeds during the disturbance. 
At the stage of colonization, the seeds will respond to favorable environmental conditions to germinate and master the initial succession stages. According to Saharjo \& Gago (2011), secondary succession affected by disturbance lasts 15 to 20 years to form a young secondary forest. It will form an old secondary forest to a climax after 50 years. The secondary succession is different from the primary succession that has accumulated in soil organic carbon during the first 50 years and the formation of a moss layer and followed by vascular plants' growth (Zehetner 2010; Fiantis et al. 2016). After that, the density, height, and complexity of plant community structure, especially understorey and trees, will be increased. Stratification, species diversity, and microclimate will be developed as a particular stage of succession (Swanson et al. 2010). This study analyzes trees' composition and stratification in a variation of forest damage after the 2010 Merapi eruption. Hopefully, this study's results can provide information on the extent of succession carried out in the MMNP forest area affected by the Merapi eruption in 2010 and see the development of the ecosystem recovery process after nine years of eruption.

\section{RESEARCH METHOD}

This research was conducted in the southern part of MMNP, precisely in Turi-Pakem Resort and Cangkringan Resort in Yogyakarta Province. Data was taken in March 2019. Sampling location was determined by purposive sampling based on the level of damage after the 2010 Merapi eruption (BTNGM 2011; Gunawan et al. 2013). According to the analysis of the MMNP officer after the 2010 eruption, there are three levels of damage as shown in Figure 1, namely red color for a location that is severely damaged where vegetation is completely destroyed by a pyroclastic flow, yellow color for a location that is moderately damaged where $60 \%$ of the vegetation burned and necromass stakes remained, while the green color is for a location that is minor damaged with the appearance of relative vegetation intact (BTNGM 2011). Data was collected at Station A on heavy damage area at Cangkringan Resort ( $7^{\circ} 34^{\prime} 54.33^{\prime \prime S}$ $\left.110^{\circ} 26^{\prime} 31.17^{\prime \prime E}\right)$, Station B on moderate damage area at Turi-Pakem Resort (7³5'19.71"S 110²6'10.98"E), and Station $\mathrm{C}$ on minor damage area at Turi-Pakem Resort (7³4'50.64"S 110²5'3.82"E).

This research consists of several stages, starting from the location survey, data sampling, and data analysis. The site survey was carried out in stages by matching the data collection area with the land damage map issued by BTNGM (2011). Each level of damage is determined by one station that represents the area. After the stations was obtained, the forest's interior was redetermined to be placed 100 meters into the forest edge. After that, the vegetation parameter data was collected for making tree profile diagrams and analyzing species diversity.

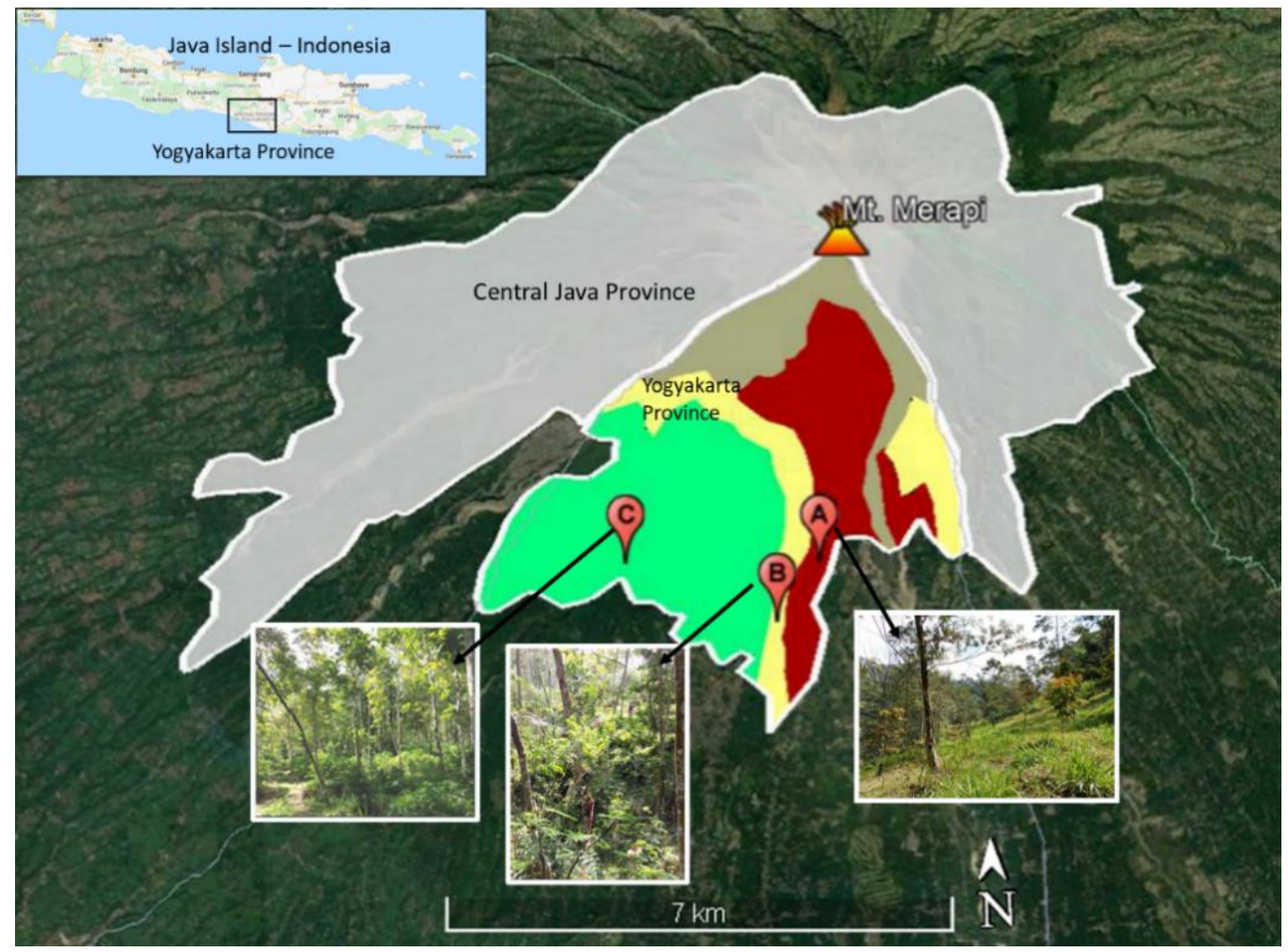

Figure 1 Sampling stations in MMNP Yogyakarta Province 
Tree stratification was analyzed using a profile diagram (Baker \& Wilson 2000; Wulandari et al. 2018) at each station by making a plot of a square in a transect line or called a belt transect (Mueller-Dombois \& Ellenberg 2016). The belt transect was made $100 \times 10$ meters long and divided into ten plots sized 10x10 meters from the forest's interior to the edge (Oosterhoorn \& Kappelle 2000). Tree stratification is illustrated by making vertical and horizontal profile diagrams. The $\mathrm{x}$ axis was expressed from the interior to the edge forest along the 100 meters. In comparison, the tree's height represented the $y$-axis in the vertical profile diagram, and in the horizontal profile diagram is illustrated with a plot width of 10 meters (Desi et al. 2017). Tree parameters data taken include species name, diameter at breast height $(\mathrm{DBH})$, tree height, the height of the first branch, tree position concerning the $\mathrm{x}$-axis and $\mathrm{y}$-axis, and canopy width (Desi et al. 2017).

This belt transect is also used in the tree structure and composition analysis, where the vegetation parameters measured are the density, frequency, and dominance of trees in each 10x10 meter plot. Trees lifeform in this study divided into small trees (woody vegetation with branches above 1.5 meters and $\mathrm{DBH}<10$ $\mathrm{cm})$ and large trees $(\mathrm{DBH} \geq 10 \mathrm{~cm})$. All tree species in the plot were sampled to be made herbarium and identified by identification book Flora of Java (Backer \& van den Brink 1965) and validation by checking theplantlist.org website. Vegetation parameters that have been recorded are analyzed using the calculation of the Importance Value Index (IVI) to observe the dominance or see tree species that have an essential role in the location (Indriyanto 2006; Utami \& Putra 2020). Besides, to describe the level of diversity in a stage of community development, the Shannon-Wienner Diversity Index (H') (1) calculation was used (Mueller-Dombois \& Ellenberg 2016). Tree carbon stock will be calculated based on the calculation of tree biomass (2) in tropical areas with rainfall between 1,500 - 4,000 $\mathrm{mm} \mathrm{yr}^{-1}$ (Brown 1997; Hairiah et al. 2001). Vegetation carbon stocks are obtained from 46 percent of the total tree biomass (Hairiah \& Rahayu 2007). Abiotic parameters, such as air temperature, air humidity, light intensity, wind speed, soil temperature, soil $\mathrm{pH}$, soil moisture, are also measured in each 10x10 meter plot. Elevation, slope, and point of coordinates were also taken as supporting environmental factors.

$H^{\prime}=-\Sigma$ pi log pi

note:

$\mathrm{H}$ '= Shannon-Wiener Diversity Index

$\mathrm{pi}=\mathrm{ni} / \mathrm{N}$ species

$\mathrm{ni}=$ total individual the-i species

$\mathrm{N}=$ total individual of all species

$\mathrm{Bt}=0.118 \times \mathrm{DBH}^{2,53}$

note:

$\mathrm{B}=$ tree biomass $(\mathrm{t} \mathrm{C} \mathrm{ha-1)}$

$\mathrm{DBH}=$ Diameter at Breast Height $(\mathrm{cm})$
Stratum data in the profile diagram, essential species with the highest Important Value Index (IVI), tree density, and tree carbon stock at each station were analyzed descriptively to compare tree stratification and composition at each damage levels of eruption. The abiotic parameters data at the study site and tree density were analyzed inferentially using the correlation test. This study's correlation test was the Pearson parametric test because the data were normally distributed and homogeneous.

\section{RESULT AND DISCUSSION}

Vegetation stratification can show a forest community's vertical structure with various levels or strata (Soerianegara \& Indrawan 2005; Indriyanto 2006; Utami \& Putra 2020). There are five levels of the vertical structure of vegetation in the forest, namely Stratum A for an emergent layer which consists of trees with a height of more than 30 meters; stratum B for upper canopy consisting of trees with a height 20-30 meters; stratum $\mathrm{C}$ for middle canopy consisting of trees with a height of 4-20 meters; stratum D for saplings and shrubs 1-4 meters; and stratum $\mathrm{E}$ for the ground layer (understorey) consisting of herbs and seedling with a height of 0-1 meters (Dinanti et al. 2018). Station A at Cangkringan Resort which suffered heavy damage after the 2010 Merapi eruption, was only dominated by trees in stratum $\mathrm{C}$ with a height range of 4 to 12 meters, as many as 16 trees/0.1 ha (Figure 2, Table 2). Acacia decurrens or Akasia Hijau from the Fabaceae family (Table 1) dominates at station A, which was also reported by Afrianto et al. (2017) and Haryadi et al. (2019) dominate in the Cangkringan and Kemalang Resort. Acacia decurrens, purple color in Figure 2, occupy open areas affected by heavy eruptions (Sunardi et al. 2017) and even tend to reduce species diversity in the MMNP area (Sutomo 2019a). Trema orientalis or Anggrung, light green color in figure 2, has the secondhighest of important value index (IVI) in this station. According to Mangopang (2016), T. orientalis is a fast growing species and a pioneer plant that can proliferate in open land experiencing disturbances. Stratum D or a sapling dominated by Syzygium polyanthum from Myrtaceae family, Green color in Figure 2, with a height range of 3 to 3.5 meters with density 7 trees/0.1 ha (Table 2). According to Gunawan et al. (2015), Salam, local name of $S$. polyanthum, and Puspa, local name of Schima walichii, are the native MMNP species commonly planted for the Merapi Volcano ecosystem's post-eruption restoration. Station A has a tree diversity (H') of 0.55, classified as low (Utami \& Putra 2020). The low diversity index value is due to the small number of individuals and species found at that location. The vertical profile diagram image (Figure 2) shows that after the 2010 Merapi eruption, Station A has still very few tree stands scattered in the research plot. Besides, the 
dominant tree stands only came from $A$. decurrens and spread in groups. The horizontal profile diagram image (Figure 2) shows that there are still very few tree canopies covering the areas. There is also a large gap between one tree canopy and another.

Station B at Pakem-Turi Resort, which suffered moderate damage after the 2010 Merapi eruption, has the highest stratum B trees reaching $21 \mathrm{~m}$ with a density of 5 trees/0.1 ha (Figure 3, Table 2). The Stratum B at this station is controlled by $A$. decurrens (purple color in Figure 3). The highest density at this station was 82 trees/0.1 ha of trees in stratum $C(20 \mathrm{~m}<$ height $\leq 4 \mathrm{~m})$, and A. decurrens also dominated it. Stratum D dominated by Caliandra calothyrsus (Dark Tan color in Figure 3) from the Fabaceae family has the second-highest density of 40 trees/0.1 ha. Tree diversity ( $\left.\mathrm{H}^{\prime}\right)$ in station $\mathrm{B}$ as a representative of moderate damage area has a value of 1.18, which is classified as moderate. Based on Figure 3, the vertical profile diagram shows that after the eruption of Merapi in 2010, tree stands had begun to form scattered across the research plots with different strata. Besides, several species are evenly distributed with the dominant altitude in this plot, namely A. decurrens. The horizontal profile diagram shows that many tree canopies cover and piled up at the sampling station. Besides $A$. decurrens, there are several species such as Albizia Vertical profile diagram

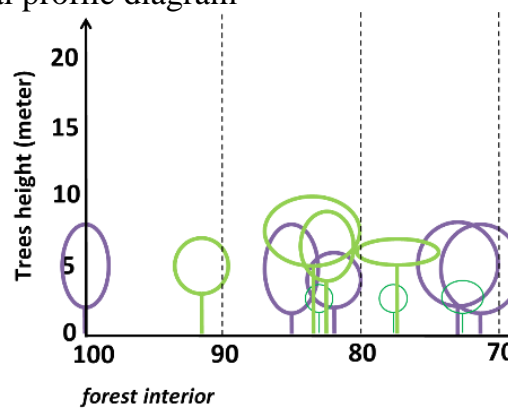

Horizontal profile diagram

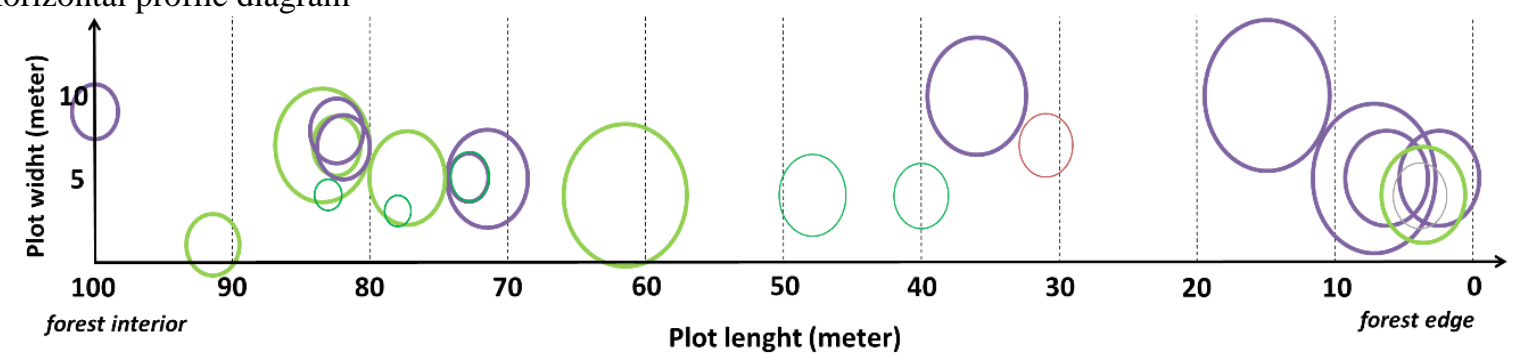

Figure 2 Profile diagram in Station A as a representative of heavy damage area

Table 1 Important value index of tree species in Station A

\begin{tabular}{clcc}
\hline Rangking & \multicolumn{1}{c}{ Species name } & Family name & Importance Value Index (IVI) \\
\hline 1 & Acacia decurrens Willd. & Fabaceae & 135.28 \\
2 & Trema orientalis (L.) BI. & Cannabaceae & 97.31 \\
3 & Syzygium polyanthum (Wight) Walp. & Myrtaceae & 44.31 \\
4 & Mallotus paniculata (Lam.) Mull.Arg. Euphorbiaceae & 11.85 \\
5 & Schima wallichii (DC.) Korth. & Theaceae & 11.25 \\
\hline
\end{tabular}


The tree arrangement in the profile diagram describes the forest stand's structure, the architectural shape, the distance between the trees, the tree size range, and the forest's age range (Leslie \& Wilson 2009). These trees' size and age can predict the history of a forest ecosystem and predict the future dominance of tree communities (Leslie \& Wilson 2009). The development of vegetation at the three research stations can be predicted through the profile diagram and vegetation density. Nine years after the Merapi big eruption in 2010, three stations are still classified as a young secondary forest characterized by the highest tree dominance in stratum $\mathrm{C}$ between 4 and 20 meters or sapling. If analyzed from tree height and tree density, stations B and $\mathrm{C}$ enter the stage of young secondary forest, which is more mature than station A. Stations B and C have grown stratum B trees with a height of more than 20 meters and density of 127 to 195 trees/0.1 ha. Station A, which has experienced primary succession, is described as entering the early stages of a young secondary forest phase. The beginning of the formation of young secondary forests is marked by species' growth with species richness that are still limited and of the same age (Finegan 1996; van Breugel 2007). Station A, the heavy damage area, experienced the slowest succession among the other two stations with the lowest tree vegetation parameters (density, richness, a high tree, carbon stock) (Figure 2 and Table 2). Development in the secondary forest will be in line with the increase in the plant community's productivity, the development of the substrate (Indriyanto 2006), the increase in diversity, and stratification (Odum 1993).

Table 2 Density, richness, and carbon stock of tree species in sampling stations

\begin{tabular}{|c|c|c|c|c|}
\hline Details & Unit & Station A & Station B & Station C \\
\hline Stratum A (height $(\mathrm{h}) \geq 30 \mathrm{~m})$ & tree / 0.1 ha & - & - & - \\
\hline Stratum $B(30 \mathrm{~m}<\mathrm{h} \leq 20 \mathrm{~m})$ & tree / 0.1 ha & - & 5 & 1 \\
\hline Stratum C $(20 \mathrm{~m}<\mathrm{h} \leq 4 \mathrm{~m})$ & tree / 0.1 ha & 16 & 82 & 172 \\
\hline Stratum D $(4 \mathrm{~m}<\mathrm{h} \leq 1 \mathrm{~m})$ & tree / 0.1 ha & 7 & 40 & 22 \\
\hline Tree Density & tree / 0.1 ha & 23 & 127 & 195 \\
\hline Tree Dominance & $\mathrm{m}^{2} \mathrm{ha}^{-1}$ & 3.97 & 11.75 & 24.32 \\
\hline Tree richness & Species & 5 & 25 & 26 \\
\hline H' Shannon Wiener & & 0.55 & 1.18 & 1.08 \\
\hline Tree carbon stock & $\mathrm{t} \mathrm{C} \mathrm{ha}^{-1}$ & 12.73 & 35.32 & 88.85 \\
\hline
\end{tabular}

Vertical profile diagram

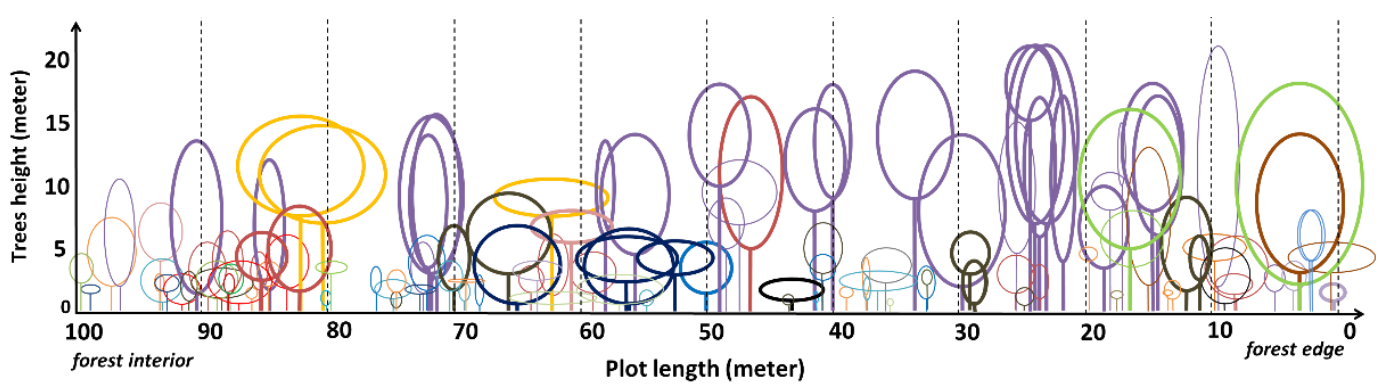

Horizontal profile diagram

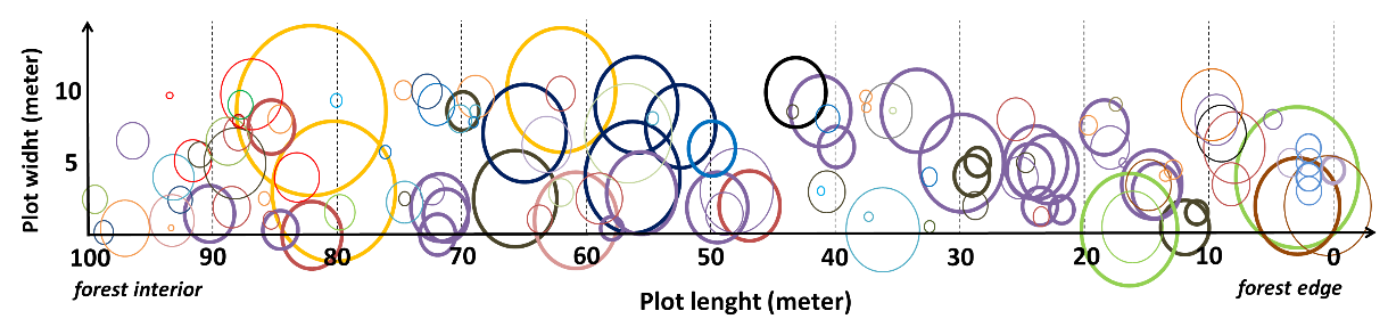

Figure 3 Profile diagram in station B as a representative of moderate damage area 
Table 3 Important value index of tree species in Station B

\begin{tabular}{clcc}
\hline Rangking & \multicolumn{1}{c}{ Species name } & Family name & Important Value Index (IVI) \\
\hline 1 & Acacia decurrens Willd. & Fabaceae & 76.57 \\
2 & Caliandra calothyrsus Meisn. & Fabaceae & 36.35 \\
3 & Schima wallichii (DC.) Korth. & Theaceae & 23.08 \\
4 & Leucana leucocephala L. & Fabaceae & 18.30 \\
5 & Albizia chinensis (Osbeck) Merr. & Fabaceae & 17.50 \\
\hline
\end{tabular}

Vertical profile diagram

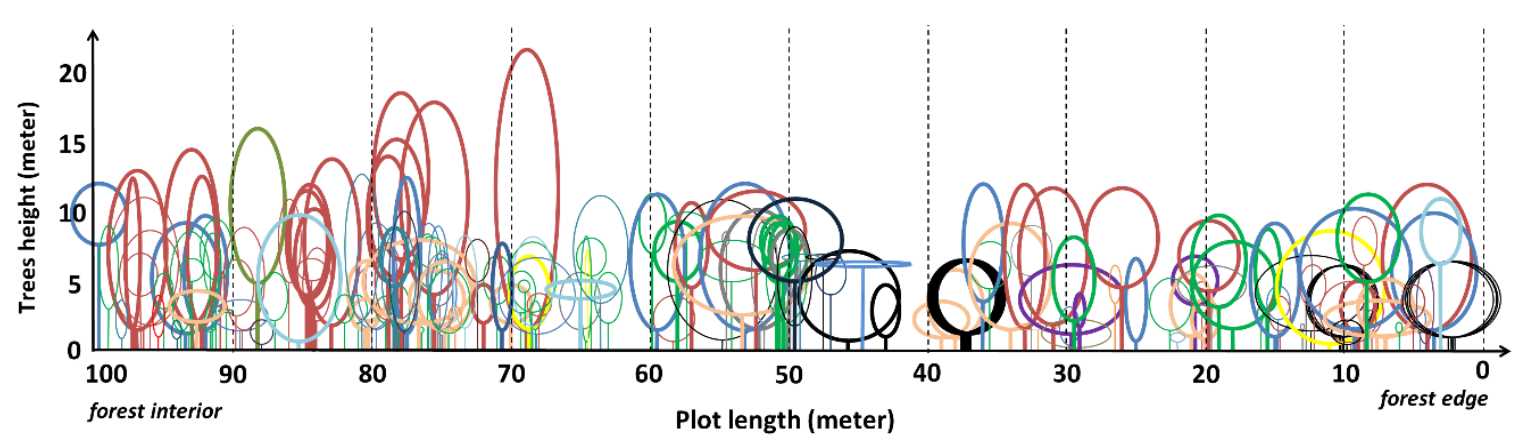

Horizontal profile diagram

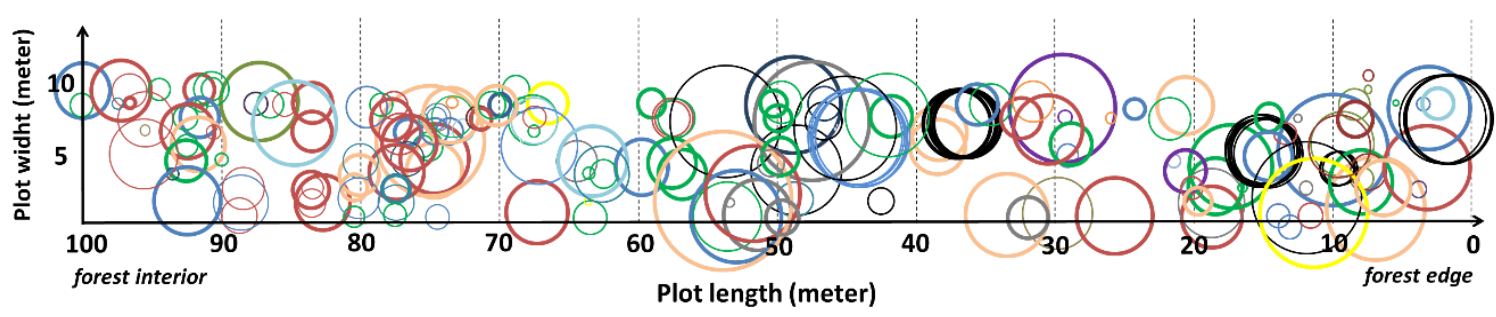

Figure 4 Profile diagram in station $\mathrm{C}$ as a representative of minor damage area

Table 4 Important value index of tree species in Station C

\begin{tabular}{clcc}
\hline \multicolumn{1}{c}{ Rangking } & \multicolumn{1}{c}{ Species name } & Family name & Important Value Index (IVI) \\
\hline 1 & Arenga pinnata $($ Wumb) Merr. & Arecaceae & 63.37 \\
2 & Schima wallichii $($ DC.) Korth. & Theaceae & 53.65 \\
3 & Syzygium polyanthum (Wight) Walpers & Myrtaceae & 44.68 \\
4 & Altingia excelsa Noronha & Altingiaceae & 30.88 \\
5 & Cestrum nocturnum L. & Solanaceae & 23.42 \\
\hline
\end{tabular}

Forest areas with high diversity can be achieved if there is an even distribution of different species and are not dominated by one species (Samin et al. 2016; Toni et al. 2017; Sutrisna et al. 2018). Stations A and B, which have an average soil $\mathrm{pH}$ ranging from $5-6$, an area slope of $4^{\circ}-21^{\circ}$, and both in an area of $1,170 \mathrm{~m}$ asl and $891 \mathrm{~m}$ asl, now appear to be dominated by Acacia decurrens. The Cangkringan area was previously composed of diverse vegetation such as Altingia excelsa, Schima wallichii, Pinus merkusii (Sutomo 2019b). However, after the 2006 eruption, which opened the crater towards Kaliadem Cangkringan, Cangkringan Resort to the east of Pakem-Turi Resort was controlled by A. decurrens (Utami et al. 2021). This plant is predicted to be an alien invasive species that grows in areas affected by eruptions both in Merapi and in Merbabu National Park
(Purwaningsih 2010; Untoro et al. 2017). Initially, this species was introduced by Perhutani in the 1980s to border the plantation area to the forest in MMNP. Acacia decurrens resistance to extreme conditions, this species began to invade the areas affected by the volcano eruption (Sunardi et al. 2017).

Acacia decurrens species can germinate and grow at low $\mathrm{pH}$, high substrate temperature (Afrianto et al. 2017) and steep slopes area (Untoro et al. 2017). The Mount Merapi National Park Office has anticipated this expansion by planting local species in the area as rehabilitation action (Gunawan et al. 2013). Planting local species such as Schima wallichii has begun to appear at the Cangkringan Resort, although it is still in a sloping area. Station B also contains introduced plants such as Albizia chinensis, starting to have a high density. 
Albizia chinensis plants were found in residents' agricultural land right next to the MMNP station B area. Station $B$ is also included in the utilization zone (BTNGM 2016) so the resident is still free to enter this area even though they cannot plant plants for personal gain.

The stratification or vertical structure of a forest can be used as an indicator that describes the diversity of vegetation and other ecosystem services, such as estimates of carbon storage (carbon stock) (Houghton 2005; Treuhaft et al. 2009; Ensslin et al. 2015). The level of diversity was influenced by number of individuals, number of species, and tree basal area (Hidayat 2017). The lowest tree carbon stock at station A (12.73 $\left.\mathrm{t} \mathrm{C} \mathrm{ha}^{-1}\right)$ and its low diversity $\left(\mathrm{H}^{\prime}\right.$ 0.55) are predicted to be associated with several vegetation parameters. Station A has the lowest tree dominance, namely $3.97 \mathrm{~m}^{2} \mathrm{ha}^{-1}$, the lowest species richness is five species and the lowest tree density compared to the other stations are 23 trees $/ 0.1$ ha (Table 2). The tree vegetation at stations $\mathrm{B}$ and $\mathrm{C}$ are included in the medium category $\left(1<\mathrm{H}^{\prime}<3\right)$ (Table 2$)$. The diversity value also can be influenced by the high density, dominance, and richness at stations $\mathrm{B}$ and $\mathrm{C}$, which is higher than station A (Table 2). Table 2 shows that the tree density at station $C$ reaches 195 trees/0.1 ha and contributes to the highest tree carbon stock value, namely $88.85 \mathrm{t} \quad \mathrm{C} \quad \mathrm{ha}^{-1}$. According to the Intergovernmental Panel on Climate Change (IPCC), the recommended carbon stock for secondary forests in Southeast Asia is above $138 \mathrm{t} \mathrm{C} \mathrm{ha}^{-1}$. This value includes aboveground biomass, necromass, and soil organic carbon (IPCC 2006). In this study, only tree biomass was calculated, so it cannot be accurately compared with the IPCC recommendation.

The three sampling stations have varying mean values in several abiotic parameters that describe specific microclimate conditions in the field (Figure 5). The condition with the lowest tree density and the canopy most open, Station A has the highest wind speed and light intensity values (Figure 5). The light intensity at station A ranges from 24,000 to $118,900 \mathrm{lux}$, and the wind speed ranges from 2.0 to $4.5 \mathrm{kph}$. The high light intensity makes the average value of air temperature and soil temperature at station A the highest, namely $28{ }^{\circ} \mathrm{C}$ and $22.7^{\circ} \mathrm{C}$. Air humidity and soil humidity at Station A were the lowest among the other two locations, namely
$51.3 \%$ and $48.4 \%$. At station $\mathrm{C}$, the microclimate conditions are the opposite of station A. Station C, which has the highest tree density with a reasonably dense canopy, has the lowest light intensity and wind speed values, ranging from 1.148 to 8.390 lux and 0.4 to 1.6 $\mathrm{kph}$. This situation makes the air temperature and soil temperature at location $\mathrm{C}$ the lowest with an average of $24.9{ }^{\circ} \mathrm{C}$ and $18.2{ }^{\circ} \mathrm{C}$. Air humidity and soil humidity at Station $\mathrm{C}$ were relatively high, namely $75.2 \%$ and $52.5 \%$. The three research stations are above $800 \mathrm{~m}$ asl, where station A occupies the highest point, namely 1,170 m asl, and station B is in the lowest location at $891 \mathrm{~m}$ asl. The measured abiotic parameters, with Pearson test, such as wind speed, air temperature, humidity, soil humidity, soil temperature, light intensity, and elevation, correlate with tree density at the three research stations (Table 5). Air humidity and soil moisture positively correlate with tree density, while other abiotic have a negative correlation. In this study, only soil $\mathrm{pH}$ does not correlate with tree density.

The microclimate in terrestrial ecosystems, such as in tropical mountain forests, plays an essential role in vegetation growth and development (Xu et al. 2004; Behera et al. 2012). These environmental parameters will also be dynamic and environmental changes that occur due to human activities or natural disasters. In Figure 5, it can be seen that microclimate conditions in open areas such as at station $\mathrm{A}$ with areas with dense vegetation such as stations B and $\mathrm{C}$ are quite different in several parameters. High enough light intensity at station A can affect the process of seed germination plus rainfall during sampling, which is in the high category, namely 300-400 mm (Ridwan 2019). Fundamentally, the processes of photosynthesis, germination, nutrient cycling, to growing height are influenced by solar radiation, wind speed, air, and soil temperature, humidity, and other abiotic properties (Davies-Colley et al. 2000; Gehlhausen et al. 2000; Beckage \& Clark 2003). Even in forest ecosystem, changes in the structure and composition of vegetation above ground level are influenced by environmental parameters and affect these parameters (Rodríguez-Ramírez et al. 2013). Ground level, slope, topography, and even gaps between the canopies influence the succession that occurs after the disturbance (Xu et al. 2004; Godefroid et al. 2006). 

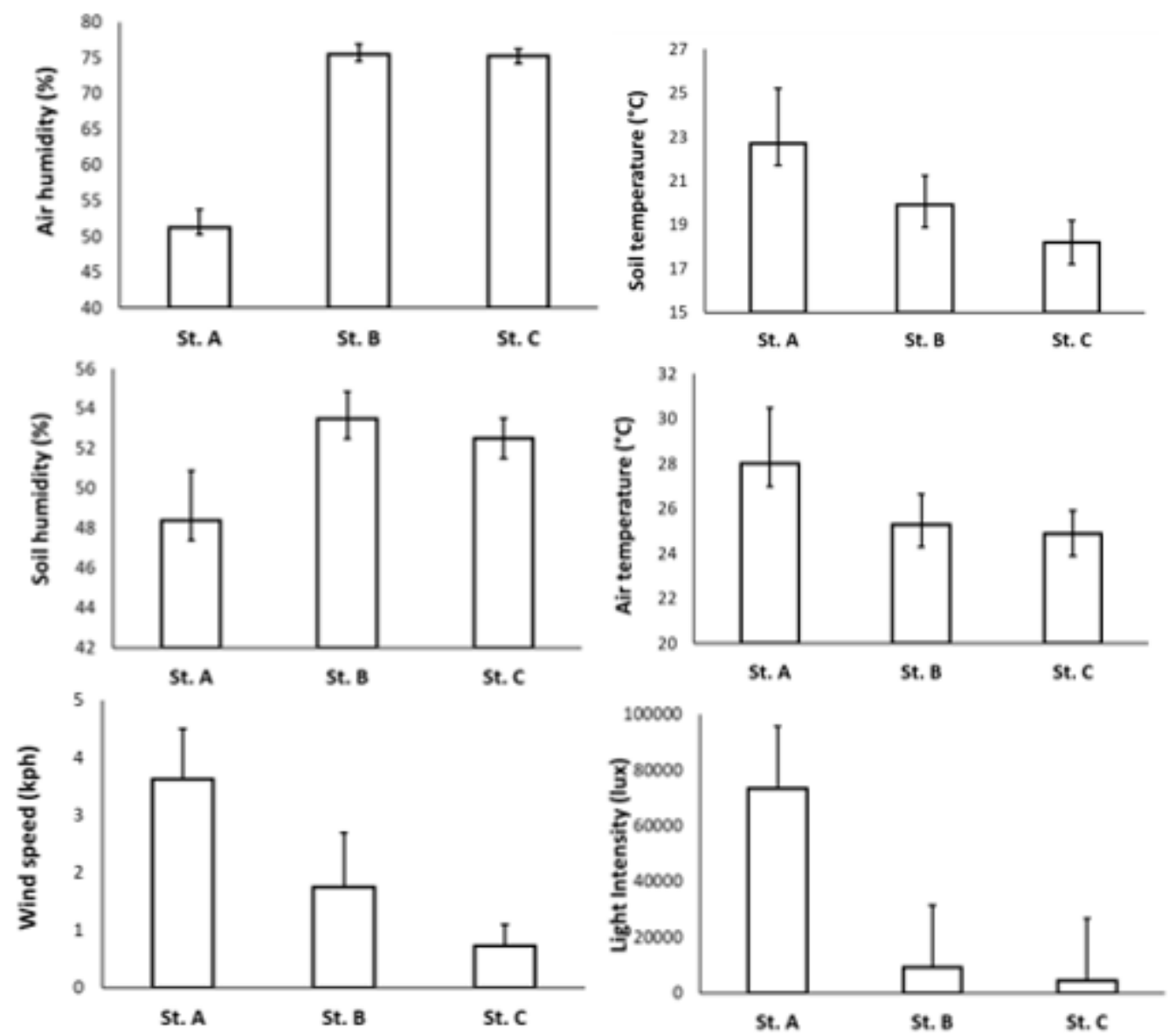

Figure 5 The average of abiotic parameters in three sampling stations

Table 5 Correlation between tree density and abiotic parameters

\section{Compared parameters}

Correlation coefficient

Sig (2-tailed)

\begin{tabular}{|c|c|c|c|}
\hline \multirow[t]{7}{*}{ Tree density } & Wind Speed & $-.801 * *$ & .000 \\
\hline & Air temperature & $-.473 * *$ & .008 \\
\hline & Air humidity & $.677 * *$ & .000 \\
\hline & Soil humidity & $.678 * *$ & .000 \\
\hline & Soil temperature & $-.817 * *$ & .000 \\
\hline & Light intensity & $-.771 * *$ & .000 \\
\hline & Elevation & $-.504 * *$ & .005 \\
\hline
\end{tabular}




\section{CONCLUSION}

Nine years after the Mount Merapi big eruption, the MMNP forests in Yogyakarta Province are still classified as young secondary forests. The three sampling stations with varying damage levels after Mount Merapi's eruption in 2010 were dominated by trees from stratum C. However, the tree composition varies at each station. Station A in the heavy damage area is still entering the early stages of the young secondary forest phase, characterized by the lowest tree density of around 23 trees/ 0.1 ha and a maximum tree height of only 12 meters. In contrast, Station $\mathrm{C}$ in the minor damage area with tree density reaching 195 trees/0.1 ha and maximum tree height reaching 30 meters. abiotic parameters, such as wind speed, air temperature, air humidity, soil humidity, soil temperature, light intensity, and elevation, correlate with tree density at the three research stations.

\section{REFERENCES}

Afrianto WF, Hikmat A, Widyatmoko D. 2016. Komunitas floristik dan suksesi vegetasi setelah erupsi 2010 di Gunung Merapi Jawa Tengah. Jurnal Biologi Indonesia. 12 (2): 265-276.

Afrianto WF, Hikmat A, Widyatmoko D. 2017. Growth and habitat preference of Acacia decurrens Willd. (Fabaceae) after the 2010 eruption of Mount Merapi, Indonesia. Asian Journal of Applied Sciences. 5(1): 65-72.

Backer CA, van den Brink RCB. 1965. Flora of Java (Spermatophytes Only) Volume II Angiospermae. Groningen: N. V. P. Noordhoff.

Baker PJ, Wilson JS. 2000. A quantitative technique for the identification of canopy stratification in tropical and temperate forests. Forest Ecology and Management. 1(127): 77-86.

Beckage B, Clark JS. 2003. Seedling survival and growth of three forest tree species: the role of spatial heterogeneity. Ecology. 84:1849-61.

Behera SK, Mishra AK, Sahu N. 2012. The study of microclimate in response to different plant community association in tropical moist deciduous forest from northern India. Biodiversity Conservation. 21:1159-76.

Brown S. 1997. Estimating biomass and biomass change of tropical forests, a primer. FAO Forestry paper 134. Rome: FAO.

[BTNGM] Balai Taman Nasional Gunung Merapi. 2011. Laporan Restorasi Ekosistem Merapi Paska Erupsi 2010. Yogyakarta: Balai Taman Nasional Gnung Merapi.

[BTNGM] Balai Taman Nasional Gunung Merapi. 2016. Zonasi Taman Nasional Gunung Merapi Tahun 2015. Yogyakarta: Balai Taman Nasional Gnung Merapi.
Cakir G, Sivrikaya F, Terzioglu S, Baskent EZ, Sonmez T, Yolasigmaz HA. 2007. Mapping secondary forest succession with geographic information systems: A Case Study from Bulan kdere, K>rklareli, Turkey. Turkish Journal of Agricultur and Forestry. 1(31): 71-81.

Chang C, Turner BL. 2019. Ecological succession in a changing world. Journal of Ecology. 2(107): 503509.

Chokkalingam U, Jong WD. 2001. Secondary forest: a working definition and typology. International Forestry Review. 1(3): 19-26.

Davies-Colley RJ, Payne GW, van Elswijk M. 2000. Microclimate gradients across a forest edge. New Zealand Journal Ecology. 24:111-21.

Desi, Linda R, Winarti I. 2017. Struktur dan profil vegetasi habitat kukang kalimantan (Nycticebus menagensis) pelepasliaran Yayasan IAR Indonesia di Hutan Lindung Gunung Tarak. Protobiont. 6 (1):1-9.

Dinanti RV, Winarni NL, Supriatna J. 2018. Vertical stratification of bird community in Cikepuh Wildlife Reserve, West Java, Indonesia. Biodiversitas. 19 (1):134-139.

Ensslin A, Rutten G, Pommer U, Zimmermann R, Hemp A, Fischer M. 2015. Effects of elevation and land use on the biomass of trees, shrubs and herbs at Mount Kilimanjaro. Ecosphere. 6(3):1-15.

Fiantis D, Nelson M, Shamshuddin J, Goh TB, van Ranst E. 2016. Initial carbon storage in New Tephra Layers of Mt. Talang in Sumatra as affected by pioneer plants. Communications in Soil Science and Plant Analysis. 47(15):1792-1812.

Finegan B. 1996. Pattern and process in neotropical secondary rain forests: The first 100 years of succession. Trends in Ecology \& Evolution. 11: 119-124

Fitria A, Banowati E. 2018. Partisipasi masyarakat terhadap pelestarian hutan lerengMerapi melalui program agroforestri kopi di Desa Tlogelele Kecamatan Selo. Edu Geography. 3(6):162-169.

Gehlhausen SM, Schwartz MW, Augspurger CK. 2000. Vegetation and microclimatic edge effects in two mixed-mesophytic forest fragments. Plant Ecology. 147:21-35.

Godefroid S, Rucquoij S, Koedam N. 2006. Spatial variability of summer microclimates and plant species response along transects within clearcuts in a beech forest. Plant Ecology. 185:107-21.

Gunawan H, Sugiarti, Wardani M, Tata MHL, Prajadinata S. 2013. Restorasi Ekosistem Gunung Merapi Pasca Erupsi. Bogor: Pusat Penelitian dan Pengembangan Konservasi dan Rehabilitasi Badan Penelitian dan Pengembangan Kehutanan Kementerian Kehutanan.

Gunawan H, Heriyanto N, Subiandono E, Mas'ud A, Krisnawati H. 2015. Invasi jenis eksotis pada 
areal terdegradasi pasca erupsi di Taman Nasional Gunung Merapi. Di dalam Seminar Nasional Masyarakat Biodiversitas Indonesia. 1(5):10271033.

Hairiah K, Rahayu S. 2007. Pengukuran Karbon Tersimpan di Berbagai Penggunaan Lahan. Bogor: World Agroforestry Center-ICRAF.

Hairiah K, Sitompul SM, van Noordwijk M, Palm C. 2001. Methods for Sampling Carbon Stocks above and below Ground. Bogor: World Agroforestry Center-ICRAF.

Haryadi, Sunarto, Sugiyarto. 2019. Vegetation analysis of the secondary forest area in Cangkringan Resort, Mount Merapi National Park. Jurnal Biodjati. 4(1):50-57.

Hidayat M. 2017. Analisis vegetasi dan keanekaragaman tumbuhan di Kawasan Manifestasi Geotermal Le Suum Kecamatan Mesjid Raya Kabupaten Aceh Besar. Jurnal Biotik. 5(2):114-124.

Houghton RA. 2005. Above ground forest biomass and the global carbon balance. Global Change Biology. 11:945-955

Indriyanto. 2006. Ekologi Hutan. Jakarta: Bumi Aksara.

[IPCC] Intergovermental Panel on Climate Change. 2006. Intergovermental Panel on Climate Change Guidelones for National Greenhouse Gas Inventories: Volume 4 Agriculture, Forestry, and Other Land Use. Japan: Intergovermental Panel on Climate Change IGES.

Leslie A, Wilson ER. 2009. The anatomy of w woodland: stand profile diagrams as an aid to problem based learning in undergraduate forestry educational. Forestry Chronicle. 85(5): 725-732.

Mangopang AD. 2016. Morfologi Trema orientalis (L.) Blume dan manfaatnya sebagai tanaman pionir restorasi tambang nikel. Di dalam Prosiding Seminar Nasional Biologi from Basic Science to Comprehensive Education. Jurusan Biologi Fakultas Sains dan Teknologi Universitas Islam Negeri Alauddin Makassar. 2 (1): 121-126.

Marhaento H, Kurnia AN. 2015. Refleksi 5 tahun paska erupsi gunung Merapi 2010: menaksir kerugian ekologis di kawasan Taman Nasional Gunung Merapi. Geoplanning. 2(2):69-81.

McNaughton SJ, Wolf LL. 1990. Ekologi Umum. Edisi Kedua. Yogyakarta: Gadjah Mada University Press.

Mei ET, Lavigne F, Picquout A, De Bélizal E, Brunstein D, Grancher D, Sartohadi J, Cholik N, Vidal C. 2013. Lessons learned from the 2010 evacuations at Merapi Volcano. Journal of Volcanology and Geothermal Research. 261:348-365.

Meiners CJ, Cadotte MW, Fridley JD, Pickett S, Walker LR. 2014. Is successional research nearing its climax? New approaches for understanding dynamic communities. Functional Ecology. 2(29):1-15.
Molles M. 2008. Concepts and Applications (Fourth Edition). New York: Mc Graw Hill.

Mueller-Dombois D, Ellenberg H. 2016. Ekologi Vegetasi Tujuan dan Metode. Yogyakarta: Yayasan Obor.

Muhamad. 2017. Tapak ekologi kepariwisataan alam pada zona pemanfaatan di Taman Nasional Gunung Merpi (TNGM) (konsep pengembangan kepariwisataan alam tematik tapak kawasan Kaliurang Kalikuning-Kaliadem sebagai kawasan budaya vulkanik). Kawistara. 7(22):207-314.

Odum EP. 1993. Dasar-dasar Ekologi. Yogyakarta: Gadjah Mada University Press.

Oosterhoorn M, Kappelle M. 2000. Vegetation structure and composition along an interior-edge-exterior gradient in A Costa Rican Montane Cloud Forest. Forest Ecology and Management. (126):291-307.

Prach K, Walker LR. 2018. Differences between primary and secondary plant succession among biomes of the world. Journal of Ecology. 2(107):1-16.

Purwaningsih. 2010. Acacia decurrens Wild.: Jenis eksotik dan invasif di Taman Nasional Gunung Merbabu, Jawa Tengah. Berkala Penelitian Hayati Edisi Khusus. 4A:23-28.

Rahayu, Ariyanto DP, Komariah, Hartati S. 2014. Dampak erupsi Gunung Merapi terhadap lahan dan upaya-upaya pemulihannya. Caraka TaniJurnal Ilmu-Ilmu Pertanian. 29(1):61-72.

Ridwan M. 2019. Analisis Curah Hujan dan Sifat Hujan Bulan Maret 2019. Jakarta: Badan Meteorologi Klimatologi dan Geofisika.

Rodríguez-Ramírez EC, Sánchez-González A, ÁngelesPérez G. 2013. Current distribution and coverage of Mexican beech forests (Fagus grandifolia subsp. mexicana) in Mexico. Endanger Species Resources. 20:205-16.

Rutten G, Ensslin A, Hemp A, Fischer M. 2015. Vertical and horizontal vegetation structure across natural and modified habitat types at Mount Kilimanjaro. Plos One. 10(9):1-15.

Saharjo BH, Gago C. 2011. Suksesi alami paska kebakaran pada hutan sekunder di Desa Fatuquero, Kecamatan Railaco, Kabupaten Ermera Timor Leste. Jurnal Silvikultur Tropika. 2(1):40-45.

Samin AN, Chairul, Mukhtar E. 2016. Analisis vegetasi tumbuhan pantai pada Kawasan Wisata Pasir Jambak, Kota Padang. Biocelebes. 10(2):32-42.

Sarmiento L, Llambi LD, Escalona A, Marquez N. 2003. Vegetation patterns, regeneration rates and divergence in an old-field succession of the high tropical Andes. Plant Ecology. 1(166):145-156.

Soerianegara I, Indrawan A. 2005. Ekologi Hutan Indonesia. Bogor: Fakultas Kehutanan Institut Pertanian Bogor.

Sunardi, Sulistijorini, Setyawati T. 2017. Invasion of Acacia decurrens Willd. after eruption of Mount Merapi, Indonesia. Biotropia. 24(1):35-46. 
Surono, Jousset P, Pallister J, Boichu M, Buongiorno M F, Budisantoso A, Lavigne F. 2012. The 2010 explosive eruption of Jave's Merapi volcano- A.

Sutomo. 2019a. Acacia decurrens di sebagian kawasan Taman Nasional Gunung Merapi Yogyakarta. Jurnal Al-Azhar Indonesia Seri Sains dan Teknologi. 5(1):38-42.

2019b. Ekologi dan potensi invasif Acacia decurrens di sebagian Kawasan Taman Nasional Gunung Merapi Yogyakarta. Jurnal Metamorfosa. 6(1):1-6.

Sutomo, Fardilla D. 2013. Floristic composition of groundcover vegetation after the 2010 pyroclastic fire on Mount Merapi. Jurnal Manajemen Hutan Tropika. 19(2):85-93

Sutrisna T, Umar MR, Suhadiyah, Santosa S. 2018. Keanekaragaman dan komposisi vegetasi pohon pada Kawasan Air Terjun Takapala dan Lanna di Kabupaten Gowa Sulawesi Selatan. Bioma: Jurnal Biologi Makassar, 3(1):12-18.

Swanson ME, Franklin JF, Beschta RL, Crisafulli CM, Dellasala DA, Hutto RL, Swanson FJ. 2010. The forgotten stage of forest succession: earlysuccessional ecosystem on forest sites. Frontier Ecological Environment. 9(2):117-125.

Toni P, Rherawatiningsih R, Sisillia L. 2017. Analisis vegetasi tumbuhan penghasil buah-buahan dalam Kawasan Tembawang Dusun Toho Raba Desa Rasan Kecamatan Ngabang Kabupaten Landak. Jurnal Tengkawang. 7(1):19-27.

Treuhaft RN, Chapman BD, dos Santos JR, Goncalves FG, Dutra LV, Graca PMLA, Drake JB. 2009. Vegetation profiles in tropical forests from multibaseline interferometric synthetic aperture radar, field, and lidar measurements. Journal of Geophysical Research. 114:1-16.

Troll VR, Deegan FM, Jolis EM, Harris C, Chadwick JP, Gertisser R, Preece K. 2013. Magmatic differentitation processes at Merapi Volcano: inclusion petrology and oxygen isotopes. Journal of Volcanology and Geothermal Research. 261:38-49.

Untoro Y, Hikmat A, Prasetyo LB. 2017. Pemodelan spasial kesesuaian habitat akasia hijau (Acacia decurens) di Kawasan Taman Nasional Gunung Merbabu. Media Konservasi. 22(2):49-63.

Utami I, Putra ILI. 2020. Ekologi Kuantitatif Metode Sampling dan Analisis Data Lapangan. Yogyakarta: K-Media.

Utami I, Yusuf FI, Husna, Fahmiatul H. 2021. Tree vegetation analysis after 10 years of Mount Merapi Eruption, 33-40. Di dalam Proceeding International Conference on Science and Engineering 4. Yogyakarta: Fakultas Sains dan Teknologi Universitas Islam Negeri Sunan Kalijaga.

Utami SN, Purwanto BH, Marwasta D. 2018. Land management for agriculture after the 2010 Merapi Eruption. Planta Tropika: Jurnal Agrosains (Jurnal of AGro Science). 6(1):32-38.

Van Breugel, M. 2007. Dynamics of secondary forests. [Ph.D thesis]. Wageningen: Wageningen University.

Wulandari I, Hendrawan R, Husodo T, Megantara EN. 2018. Vegetation structure and composition in Ciletuh Geopark, Sukabumi, Indonesia. Asian Journal of Forestry. 2(2):54-61.

Xu M, Qi Y, Chen J. 2004. Scale-dependent relationships between landscape structure and microclimate. Plant Ecology.173 :39-57.

Zehetner F. 2010. Does organic carbon sequestration in volcanic soils offset volcanic $\mathrm{CO} 2$ emissions? Quaternary Science Reviews. 29(11-12):13131316. 